\title{
The Mycoside Capsule of Mycobacterium avium 357
}

\author{
By P. DRAPER \\ National Institute for Medical Research, Mill Hill, London $\mathrm{NW}_{7}$ I $A A$
}

(Received 25 January 1974)

INTRODUCTION

\begin{abstract}
Draper \& Rees (1973) have shown that Mycobacterium lepraemurium, an obligate intracellular parasite of small rodents, surrounds itself, inside the phagocytic cells of the infected host, with a capsule of peptidoglycolipid having a fibrillar appearance in the electron microscope and chemically resembling the main mycoside of $M$. avium (Voiland, Bruneteau \& Michel, 197I). It seemed of interest to discover whether the latter substance had a similar ultrastructure and location.
\end{abstract}

\section{METHODS AND RESULTS}

Mycobacterium avium 357 (kindly supplied by Dr J. Stanford) was grown in Sauton's (1912) medium, unshaken, for 7 weeks at $37^{\circ} \mathrm{C}$. Cultures were sterilized with gamma radiation $\left(2 \cdot 5 \mathrm{Mrad}\right.$ from $\left.{ }^{60} \mathrm{Co}\right)$ before handling.

Bacteria were harvested by centrifuging at $10000 \mathrm{~g}$ for $10 \mathrm{~min}$; the supernatant medium contained no fibrillar material. The bacteria were homogenized in $0.3 \mathrm{M}$-sucrose, buffered with 2.5 mM-potassium EDTA to $\mathrm{pH} 7.2$ (conditions used by Draper, 1971, for mouse livers infected by $M$. lepraemurium), centrifuged at $10000 \mathrm{~g}$ for $\mathrm{I} 0 \mathrm{~min}$ to collect bacteria and then at $30000 \mathrm{~g}$ for $1 \mathrm{~h}$. The high-speed sediment was suspended in water for electron microscopy, then freeze-dried, dissolved in chloroform, mixed with an equal volume of methanol, centrifuged (to remove a small residue of bacteria), evaporated and weighed.

Homogenizing removed $2.4 \mathrm{mg}$ from $385 \mathrm{mg}$ of cells $(0.62 \%)$ of material soluble in chloroform $(0.66 \%$ in a second experiment). Negatively stained suspensions had a fibrillar structure, with individual fibrils arranged in parallel bands (Fig. I $a$ ). The fibrils had a diameter of $6.8 \mathrm{~nm}$. Even after homogenizing, the bacteria possessed a capsule of similar material (Fig. $\mathrm{r} b$ ).

Thin-layer chromatography (technique of Draper \& Rees, 1973) showed the presence of one major and a number of minor glycolipids. The range of mobilities was similar to that of the glycolipids from the capsule of $M$. lepraemurium, but no individual spot had the same mobility as a component of $M$. lepraemurium.

The fibrillar material from $M$. avium contained 6-deoxyhexose, equimolar amounts of alanine, threonine and alaninol, and smaller amounts of phenylalanine, leucine and valine (analyses by the methods of Draper \& Rees, 1973).

Homogenized bacteria were freeze-dried, weighed and extracted with ethanol-ether ( I : I by vol.) for I week ( 4 changes). The evaporated lipid extracts were treated with ether, and the ether-insoluble portion (authentic mycoside; Voiland et al. 197I) was collected and weighed; $2 \mathrm{I} \cdot 5 \mathrm{mg}$ was obtained from $386 \mathrm{mg}$ of bacteria $(5.6 \%)$, and consisted of the same substances in the same relative proportions as the fibrillar material removed mechanically, judged by thin-layer chromatography. 

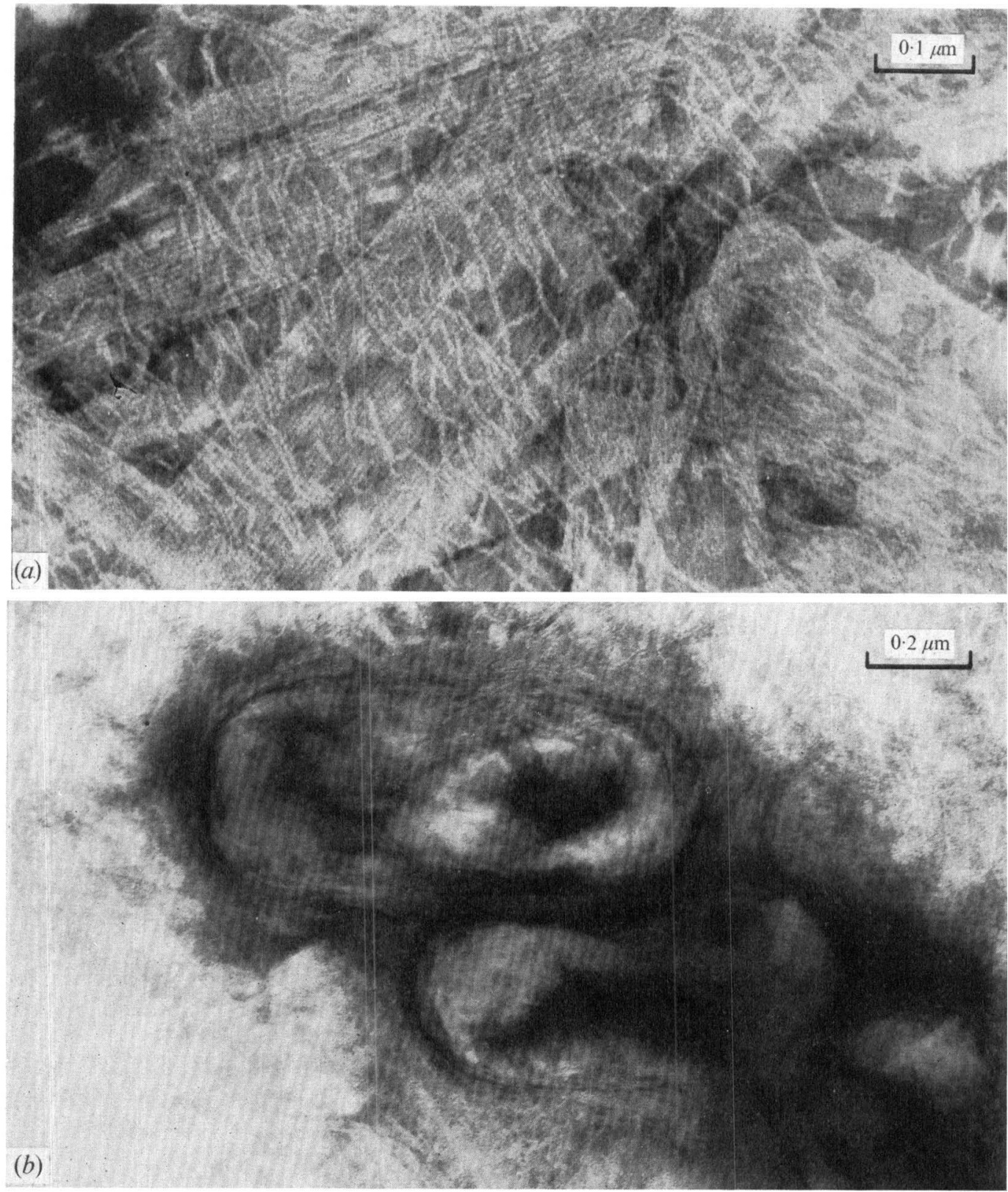

Fig. I. (a) Electron micrograph of fibrillar material (mycoside) removed from Mycobacterium avium by homogenization. Negatively stained with sodium silicotungstate. (b) Electron micrograph of cells of Mycobacterium avium showing fibrillar material still adhering after homogenization. Negatively stained with uranyl acetate.

\section{DISCUSSION}

The chemistry of the major mycoside of $M$. avium has been thoroughly studied (Jollès, Bigler, Gendre \& Lederer, I96I; MacLennan, I962; Chaput, Michel \& Lederer, 1963; Vilkas, 1966; Bruneteau, Michel \& Guilluy, 1968; Voiland et al. 197I). Our results showed 
that material with the same chromatographic properties as authentic mycoside, and containing the expected sugars and amino acids, could be removed from the bacteria by homogenizing them under conditions that are known to remove the mycoside from cells of $M$. lepraemurium, in spite of the difference in culture methods. Such homogenization removed only about $10 \%$ of the mycoside of $M$. avium. No particulate glycolipid occurred in the medium in which $M$. avium had been grown, but fibrillar material could be seen adhering to the cells after homogenizing. Evidently the mycoside capsule of $M$. avium was more firmly attached than that of $M$. lepraemurium (which may perhaps have been loosened by the action of the host cell containing the bacteria).

Morphologically the mycosides of Mycobacterium avium and $M$. lepraemurium were similar. The diameters of the individual fibrils, 6.8 and $7 \mathrm{~nm}$ respectively, were probably identical within the uncertainties of measurements from electron micrographs.

Mycobacterium avium and $M$. lepraemurium are severe pathogens in their respective hosts and the 'natural' environment of both species is the phagolysosome of the host cell (Hart, Armstrong, Bron \& Draper, 1972; Draper, unpublished results). There is immunological evidence, both from serology (Kwapinsky \& Kwapinsky, 1973; Stanford, 1973) and immunization experiments (I. N. Brown, unpublished results) that the species are closely related. Apparently they protect themselves from the environment with similar layers of mycoside.

I am grateful to Dr R. J. W. Rees for arranging the supply of M. avium.

\section{REFERENCES}

Bruneteau, M., Michel, G. \& Guilluy, R. (1968). Isolement et identification du di-O-méthyl-3,4 1.rhamnoside d'alaninol à partir du mycoside $\mathrm{C}_{2}$. Comptes rendus hebdomadaires des séances de l'Académie des sciences $\mathrm{C} \mathbf{2 6 7}, \mathbf{7 4 5}-\mathbf{7 4 8}$.

Chaput, M., Michel, G. \& Lederer, E. (1963). Structure du mycoside $\mathrm{C}_{2}$ de Mycobacterium avium. Biochimica et biophysica acta 78, 329-34I.

DRAPER, P. (I971). The walls of Mycobacterium lepraemurium: chemistry and ultrastructure. Journal of General Microbiology 69, 3I3-324.

Draper, P. \& ReEs, R. J. W. (1973). The nature of the electron-transparent zone that surrounds Mycobacterium lepraemurium inside hest cells. Journal of General Microbiology 77, 79-87.

Hart, P. D’A., Armstrong, J. A., Brown, C. A. \& Draper, P. (I972). Ultrastructural study of the behaviour of macrophages towards parasitic mycobacteria. Infection and Immunity 5, 803-807.

Jollès, P., Bigler, F., Gendre, T. \& Lederer, E. (i96i). Sur la structure chimique du 'mycoside C', peptido-glycolipide de Mycobacterium avium. Bulletin de la Société de chimie biologique 43, 177-192.

KWAPINSKY, J. B. G. \& KWAPINSKy, E. H. (I973). Immunological reactions of Mycobacterium leprae and Mycobacterium lepraemurium grown in cayman. Canadian Journal of Microbiology 19, 764-766.

MacLennan, A. P. (1962). The monosaccharide units in specific glycolipids of Mycobacterium avium. Biochemical Journal 82, 394-400.

SAUTON, B. (1912). Sur la nutrition minérale du bacille tuberculeux. Comptes rendus hebdomadaires des séances de l'Académie des sciences C $\mathbf{1 5 5}, 860-86 \mathrm{I}$.

Stanford, J. S. (1973). An immunodiffusion analysis of Mycobacterium lepriemurium Marchoux and Sorel. Journal of Medical Microbiology 6, 435-439.

Vilkas, E. (1966). Analogie des structures des mycosides $\mathrm{C}_{2}$ de Mycobacterium avium et $\mathrm{C}_{\mathrm{b}}$ de Mycobacterium butyricum. Comptes rendus hebdomadaires des séances de l'Académie des sciences $\mathbf{C}$ 262, 786-788.

Volland, A., Bruneteau, M. \& Michel, G. (I97I). Étude du mycoside $C_{2}$ de Mycobacterium avium. Détermination de la structure. European Journal of Biochemistry 21, 285-29I. 